\title{
Modern War as a Cultural Phenomenon. Causes of War. Results of the Associative Experiment with "Modern War" Associate (Based on Research Carried Out in the Student Groups of Siberian Federal University)
}

\author{
Natalia P. Koptseva and Kseniya V. Reznikova* \\ Siberian Federal University \\ 79 Svobodny, Krasnoyarsk, 660041, Russia
}

Received 23.11.2014, received in revised form 09.01.2015, accepted 11.03.2015

\begin{abstract}
The present research studies images and concepts of collective perception of modern war in the modern student youth medium. The research involves the latest theoretic, conceptual, methodological achievements common for foreign and Russian researchers of international relations, military conflicts, modern war specificity, modern war causes analysis. The empiric study applies the free association experiment method based on the methodology by Nazarov and Sokolov. The word combination "modern war" acts as a stimulus. The empiric study was carried out with 100 students of Siberian Federal University majoring in technical and humanitarian subjects. As a result, around 900 associates were collected and classified based on their types and qualitative properties. The results were processed and interpreted. The most frequent associations with the "modern war" stimulus are: "information war" and "nuclear war". The collective perception of modern war in the student youth medium of Siberian Federal University may be extrapolated to the wider social strata of students and young people of the Russian-speaking population of the Russian Federation. The research results may be used for political decision-making, youth policy program planningfor patriotic education of citizens and appropriate understanding of the Krasnoyarsk region youth.
\end{abstract}

Keywords: modern war, war causes, level analysis, national (state) level, free associatiation experiment, concept, student youth, Siberian Federal University, information war, national security.

DOI: 10.17516/1997-1370-2015-8-8-1591-1610.

Research area: culture studies, philosophy.

\section{Introduction}

On September 2014, in his sermon delivered on the Austro-Hungarian memorial Fogliano Redipuglia in Gorizia Pope Francis said: "World War III is already with us". The ceremony where these words were uttered was dedicated to the centenary of World War I. Pope Francis spoke of the new war as "irrational", and among its causes he named "greed, intolerance, the lust for power". He said that one could speak of a third war, one fought piecemeal, with crimes, massacres, destruction. The words of Pope Francis, spread

(C) Siberian Federal University. All rights reserved

* Corresponding author E-mail address: axu-ta@mail.ru 
around the world by global media, are unlikely to be "random".

The events in the South-East of Ukraine, the proclamation of the Islamic State of Iraq and the Levant are interpreted by many experts as "pre-wars" that foresee the active phase of a world war between the leading geopolitical players including the United States of America, countries of the European Union, Russia, China, and Japan. Some economists suggest that the rising financial crisis may be only "relieved" by "force-majeure circumstances the "world war" is, no doubt, related to". Other experts suppose that the unipolar world and globalization prevent the emergence of military conflicts in the territories of the developed, first world countries, while multipolar or even bipolar world inevitably turns into the space for continuous war not only between the leading economic players, but also in the periphery of the global world, on state borders, within state territories, between ethnic and confessional groups.

We may also register an explicit and implicit "war religion" both in the global mass culture and regional cultural spaces. The cult singer, composer and poet Viktor Tsoi expressed this "war religion" in his well-known verse: "War is the work of the young, medicine against wrinkles". War is the basis of the historical and cultural memory of every ethnocultural group. It is evident that it is connected with the social experience of the ethnocultural groups' separating from each other with the territorial border, as well as the ideology of supremacy of their social institutions over the social institutes of the other ethnocultural groups. The phenomenon was analyzed by Erich Fromm in his book "The Anatomy of Human Destructiveness" and referred to as "social narcissism".

Mineev V.V. reveals the sophisticated social dialectics of the two mythologems "holiness of life" and "absolute value of humankind". In his book "Departure from Life: Social and Philosophic Perspective" he demonstrates that politicians make excuse of anything using the mythologems, as the mythologems haveno cosmic-natural-objective grounds. The same philosopher points out that the prohibition of death penalty blurs the boundaries between the lawful and unlawful deprival of life and returns vengeance back to the level of people, family, and friends. Therefore, modern war may originate from an unexpected cause: being deprived of its form as a state-performed death penalty, vengeance comes back as a war.

\section{Definition of war}

War is a "large-scale organized violence between political organizations". This is how war is defined by a famous modern research of war and its causes Jack S. Levy (Levy, 1983; 1998). In a similar way war is defined by John Vasquez (Vasquez, 2009). Among other forms of violence, war has its distinctive features: from the minor forms of violence, war differs with the number of killed victims. The minimal number of victims in a war is 1000 people.

In the military and political dictionary "War and Peace in Terms and Definitions" war is defined as a "social and political phenomenon connected with the root change of relations between states and nations, and the change from non-violent forms and means of struggle to immediate use of weapons and other violent means of armed struggle for achievement of some definite economic and political purposes". Though somewhat cumbersome, this definition is wide and descriptive enough.

Here war is not specified in respect with any other forms of violence, but is opposed to "non-violence" as a whole. It provides to statistic 
criteria, does not mention the minimum number of victims for a violent deed to be referred to as "war". It emphasizes the technical aspect, mentioning weapon as the main attribute of a military conflict.

Emphasis on the technical side of war, which is the use of weapon, is made in other definitions of war formulated by Russian researchers. Thus, G.V. Liutkene summarizes the achievements of Russian military theory to create an integrative definition of war as a "bilateral armed conflict of antagonistic opposite forces, manifesting itself in a massive and wide-scale way, leading to human victims and losses".

It is evident that the interpretation of war is changing. The general definition of war may not be up-to-date any more, as modern military theory distinguishes between "major" and "minor" wars. For a long while, researches have been focused on the "major", "international", "universal", "great", "global" wars: the wars that lead to significant changes in the international structure. Jack S. Levy suggests that the emphasis on such "hegemonial" wars is connected to the "Europe-focus" of the researches. K. J. Holsti finds it necessary to research the "low intensity wars" and "identity wars".

Modern war is a complicated, multi-layered cultural phenomenon. Modern war analytics requires the subject matter war to be specified. After that the war type is analyzed both as an objective process and as an image, in the process of formation influenced by some cultural and psychological factors. In their turn, the cultural and psychological factors influencing the modern war image are bound to cultural memory, language, and symbolic complexes, the collective sense carriers.

Modern war has its causes determined both by cultural universals and cultural peculiarities of a certain social group, including cultural peculiarities or a nation or an ethnos.

\section{Causes of war as \\ a theoretic problem}

Causes of war are being studied in several theoretical aspects. The first one is associated with the answer to the question: why does the war ever happen? What is the urge for war?

Usually these questions are answered by pointing at aggression as the core of human nature.

Thus, hypotheses on the aggressive behavior involving killing others to protect the habitat of a biosocial community being typical for not only humans, but, for instance, for chimpanzees, appear more and more often (especially in popscience publications). One of the main conclusions promoted by the researchers of the chimpanzee's aggressiveness is formulated as follows: the acts of killing are directly connected to the number of males in the group and the "density of male population in the territory".

There is a similar well-known demographic theory of "young man domination" based on division of labour, used to explain the causes of "human" war. From the point of view of Gaston Bouthoul, Jack Goldstone, Gary Fuller and Gunnar Heinsohn, the cause of war is the excessive population of young men who have no significant heritage in respect with the vacancies they could have taken, which would have been acceptable in the current division of labour existing in the society. Thus, Gunnar Heinsohn deduced a demographic ratio, critical for the society where $30-40 \%$ of the population belongs to the age category of 15-30 years old. As a rule, such demographic proportion occurs after a demographic boom. Heinsohn suggests 2.1 children per one man and one woman is enough for mere reproduction of the existing and established number of population. As the sociologist claims, increase in the number of children leads to crime, rebellions, revolutions, civil wars, genocides and conquests (wars). 
In his famous book "Clash of Civilizations and Remaking of World Order", S. Huntington (1996) also relies on the "young men theory", explaining the activeness of Muslim communities not only by the charisma of Islam as a religion, but also as a demographic process associated with the birth rate increase in Islamic societies and states. Distinguishing between 8 main types of civilization, S. Huntington suggests that conflicts (wars) of the future would occur not on the borders between states, but on the borders between civilizations. He names six main causes for such new wars: 1) fundamental differences between civilizations; 2) growth of civilization self-consciousness; 3) revival of confessional identification and self-identification to replace the territorial and ethnical ones; 4) longing for the "origins" the "non-Western" civilizations, apparent "de-Westernization" of the elite; 5) conflict between the cultural identities; 6) formation of a new economic regionalism. Back at that moment, Huntington points at the civilization conflict's not being related to any territorial or state borders. It may occur just as the conflict between the Christian and Muslim population of the Balkans, or as the domestic Indian conflict between Indians and Muslims. Huntington predicts civilization conflicts of the future, including the conflict between Russian nationalism and Western liberalism. Moreover, as Huntington supposes, the conflict is more of an external than internal nature, as all the elites of Russia are split. A part of them is trying to lure the community into the Western civilization borders, while the other is ready to do whatever it takes to oppose, causing an extremely hostile attitude of the Western elites.

The main forecast promoted by Huntington states that all other, non-Western civilization would subsequently rise against the Western one. All of them want to get rich, enjoy modern technologies and modern education, modern professional qualifications and modern weapons, retaining, at the same time, their civilization identity. As Huntington suggests, until now Japan has been the only one to succeed. But Russia is striving to do the same. 7 years after Huntington's article published in Russian language, this major forecast began to come true. Every day mass media brings us new proofs of the "civilization conflict" prophet's being right. Therefore, the conflict of civilizations on the borders of the civilization is more of competitive, than military type.

From the recent Russian history we may consider the incorporation of the Crimea. For Russians the absence of military, so-called "polite people" was the factor that legitimized the process of incorporating the Republic of Crimea into the number of the constituent entities of the Russian Federation. The concept of "war" as a ground for the major domestic and international political events is one of the Russian nation's cultural codes. War does not only act as a reason for destruction and legalized mass slaughter; war is an impulse for creation of new enterprises, technologies, industrial force production. However, the major production force is a person. Often the warring societies are the ones to create new breakthrough medical technologies to save people's lives despite the heaviest biological damage of body and psyche. As for the psychic consequences of the world, regional and civil wars, Richard Gabriel studied them in his work "No More Heroes: Madness and Psychiatry in War". The main idea of the book claims, that states and nations are accustomed to counting military expenses in the monetary equivalent or by the number of killed and wounded. But what about the suffering caused by war? Richard Gabriel states that the veterans who have took part in real battles are more likely to suffer from mental disorders rather than from physical wounds. The researchers of psychiatric consequences suffered 
by the American participants of World War II Stéphane Audoin-Rouzeau and Annette Becker say, that $98 \%$ of the veterans are in need for psychiatric assistance of different types. I believe that this scary ratio is the same for all social organisms, despite their ethnical and cultural belonging.

The second aspect of studying the causes of war is closely bound to the answers to the following questions. Why does war occur at this time and in this territory? Why does it happen between these two political units, not any other? Why does it happen in the age of these governors, not any other? How did this cultural and historical context contribute to the war?

And, finally, the third aspect of studying the causes of war is the one usually considered by historical science. It is the answer to the question on the certain reasons of the given war.

K.N. Waltz supposes that the main cause of war is the randomness (he uses the term "anarchy") of the international system unlike the well-ordered domestic political system. From the point of view of K.N. Waltz, at the present moment there are neither mechanisms to force the termination of war, nor legitimate mechanisms to settle the interpolitical and international disputes that transform into war. As claimed by J.S. Levy, the anarchism of the international system explains the interchange of war and peace, but does not explain the reason for it, i.e. if anarchism is a constant always typical for the international system, then how can the presence of peace and termination of war be explained?

The same questions are raised by feminist theories of war explaining it by the domination of patriarchal societies. If the patriarchal institutions of power act as the social constant, they do not explain the fundamental cause of war. As a rule, feminist researches of war focus on studying the consequences of war for women. Feminism establishes the causes based on the gender proportion in the society before the war, arriving at the conclusion that all patriarchal societies inevitably find themselves in the state of war. Such ideas are typical for Jean Elshtain, Cynthia Enloe, Spike Peterson, and Christine Sylvester.

Jean Elshtain is the doubtless classic of researching gender roles at war. She studies two main gender roles: "man the brave warrior" and "woman the peace maker". The conclusions of Jean Elshtain claim that man's behavior at war is the behavior of an immature teenager who does not know how to defend his interests in any other way besides fighting, while the woman's behavior at war is the behavior of a mature patriot having the experience of an adult; for this reason, such type of behavior ("experienced adult") is more efficient at war.

Cynthia Enloe also suggests that violence is an aspect of the man's gender role, though it is not only the man who may act as the violent one. She makes a detailed analysis of the man's gender mechanisms in the formation process of the United Nations and the organization of American military system. S. Enloe provides a thorough explanation of how the gender stereotypes of masculinity are manifested in international relations and in the work of the UN in particular, in international trade etc. She concludes that international relations tend to defend, first of all, the gender interests of the man, while the rights and problems of women and girls are initially taken as "minor". S. Enloe comes to the conclusion that without understanding the purposes and rights of women in the international relations one may not draw the definition of "masculinity" and that the international political relations are in need of both masculine and feminine ethics.

Giving proper respect to the feminist studies of war and the neo-realistic concept of the anarchic causes of war, we cannot but notice that in all those studies war is regarded in the social state of statics, being something typical 
of all social organisms, while simple empirical researches usually say that the peaceful state of society dominates over war. Consequently, the problem includes the understanding of the fundamental cause of war that "tears the peace apart" and transforms a social mechanism into the state of war.

To unveil this fundamental cause, we need to accumulate some researches connected with the understanding of the anarchy forms the international system has before the beginning of war, and with the certain gender scenarios that existed in the patriarchal societies that could transit from the state of peace to the state of war with relative ease.

\section{Levels of war causes analysis}

The creator of level analysis of war is Kenneth Neil Waltz (1924-2013), a famous international relations specialist, political scientist, the author of the political science concept for neorealism (structural realism). The concept for realism, in particular, explains the sustainability of the bipolar world and reveals the stable forms (patterns) for international relations including war patterns with the help of the theory of anarchy of the international systems. Neorealism is based on the fact that no one needs safety of a certain state besides the state itself and its political leader. The national safety enhancement means enhancement of this state's power. Consequently, growing its power the state automatically becomes a competitor, an enemy for other states. In this regard Kenneth Waltz suggests that international conflicts and wars are an "eternal", or, at least, a constantly reproducing aspect of international relations. Therefore, neorealism claims that inclination for war is a regular consequence of the bipolar international system. In one of his interviews published in Russian in the year 2013, Kenneth Waltz characterized the state of peace as "decadence" of a state, making references to the peaceful lives of Athens and Sparta when such state as Rome emerged.

The levels of analysis for the causes of war were revealed by Kenneth Waltz in his book "Man, the State, and War" (1959) where he suggested the classification of wars by their origins: individuals, states and international relations, which Waltz referred to as the explanations of the first, second and third image. At the moment there are some modifications of this pattern. Sometimes the individual and state causes merge together, forming the two-level levels of war analysis outlining the national and systematic (international) images. Often, following the latter works by Kenneth Waltz himself (after his famous "Theory of International Politics", 1979), the state (national) image is divided into the image of the government and society. The levels of war cause analysis dominate in the international relations theory today. A great number of scientific discussions are based on the specification of relevance of this or that image for the emergence of war. Where does this integral feature leading to war occur: at the level of a bureaucratic organization, an international system, or national decision-makers?

Each of the images has its own objective space for analysis. The systematic level of analysis reveals itself through various models of the international system and the review of this system's functioning results. With the use of the two levels' pattern: national (state) and systematic (international) images, the state interaction strategies are in focus. At the state (national) level, the international policy of a state is studied. Individual image of causes of war describes the choice, opinions, and preferences of certain personalities who have an opportunity to express their political will.

Describing the analysis of the war levels, Jack S. Levy fairly mentions that the variables that explain the causes of war at this given level 
cannot do the same at the other given level of the analysis. The variables detected at various levels may have no cause-and-effect relationships between each other. For example, we have found which convictions and which individual political choice pushed a person to make a decision to initiate a war. But this understanding does not explain the state strategy in its relations with another state, which is the cause for the war at the state (national) level. And though the causes of a certain war must be revealed at the systematic and state level, they are not likely to be the most important and the most critical for the beginning of this war.

At the present moment, the methodology of analyzing levels of modern war causes is being developed, and it is closely bound to the object of the current research. This research focuses on the national level that is restricted to Russian society. Thereby, some problematic aspects occur:

1) Russian nation is currently going through the process of establishment; national cultural identity is forming in the modern process of the identification and self-identification of Russia;

2) just like any other modern society, Russian nation is a compound, multi-layered social organism, the different elements of which are dramatically different from each other; therefore, they construct the modern war image in different ways. It means that it is necessary to outline a certain social group within the modern Russian nation and study the attitude to war in this given social group;

3) it is necessary to distinguish some objective processes the Russian nation has already got involved into (global economic, political processes, Russian domestic economic and political processes, cultural processes connected with the historical memory, collective conscience, collective unconscious etc.), and the collective image that is formed around the concept of "modern war".
These are not the objective processes, but the cultural and psychological process of forming the "modern war" concept that this research is devoted it. It causes the choice of the analysis method, which is the associative experiment. Moreover, for the research from the whole multilayered social organism of Russia one of the most interesting social groups was selected, which is the student youth. The choice is explained by the fact that in the nearest future these people are expected to become the most active social figures. These are their actions and their activities that define our future and create the social context for these or those significant political events to unwind.

\section{Free association experiment with the "modern war" associate}

Free association experiment which is used in this research to study the modern war phenomenon is a method that emerged back in the late 19 century. According to some data, the pioneer of this method was British scientist Sir Francis Galton. In the year 1879 he tried this specific method with the following procedure. He wrote 75 words on 75 cards and put them off for several days. After a while he returned to the cards, turning each one over and writing two associations that came to his mind as he read the words. The results of the experiment were destroyed by G. Galton as they revealed the core of the thinking process so clearly that there was no relevant form to describe and publish it without making it obscure.

To "reach the darker sphere of a person", the free association experiment was also practiced by C. G. Jung. He called the free association experiment "verbal associations" or "mental associations" and thought it to be one of the three tools, along with dream analysis and "active imagination method" to reveal the archetypical images of the collective unconscious. C.G. Jung 
offered the respondents a list of one hundred words, crossing them out one by one and recording the time spent on writing down the association. Besides the temporal factor, C.G. Jung also noticed the reaction that accompanied the association. If the patient looked nervous or hesitant, C.G. Jung paid special attention to the stimulus causing the reaction, supposing that it was the evidence of the respondent coming across a complex. After the trial of all the words, C.G. Jung repeated the list again, paying attention to the stimulus words the reactions to which at the first and second reading did not match. During his practice, C.G. Jung outlined 12 types of reaction disorder he found necessary to study. "If you want to know what bothered the person, take a look at the words that caused the disorder. Bind them together, and you will get a nice story".

After C.G. Jung psychologists continued using the free association experiment; in modern science it is also used in linguistics, sociology, and political science. For example, it reveals the true mood of the electorate much better than regular social surveys. Here we may also mention the work by E. Krasova who studied the images of federal and regional (Voronezh Region) politicians using a focused free association experiment (associations with birds, flowers and book characters); and an article by T.A. Bondarenko who studied the perception of law enforcement bodies.

Along of the practice of the free association experiment, the theory is also developing: new experiment types (such as free and focused) are distinguished, the sampling methods are discussed etc. Thus, concerning the sampling issue, the researchers suggest that the most efficient way of conducting the experiment is addressing the audience of youth aged 17-25, as "the stimulus language is a native language to them. It is believed that the vocabulary and linguistic capacities of the person usually reach the top point by this age.
Psycholinguistics suggest that for the majority of people these features remain relatively stable for the whole of their lives". However, the errors of exclusive addressing the young audience should also be taken into account. In particular, we may suppose that the results obtained from surveying the young and elderly respondents on the issue of the modern war phenomenon may be different, as these two population groups prefer getting information from different sources: for the first one it is majorly Internet, while the second prefers TV and printed media.

In the present work, the free association experiment with the stimulus "modern war" was carried out among bachelor and master's degree students of Siberian Federal University majoring in humanitarian and technical subjects. The total number of participants was 100 people. The total number of obtained associations was 892 , which is almost nine associations per person. Out of the total number of associations, there were 248 neutral (27.80\%), 573 negative (64.24\%), 71 positive $(7.96 \%)$. That means that the number of the negative associations exceeded that of the positive by 8 times.

Further let us study the most frequent associations. They shall be presented in two tables. In Table 1 associations are shown in the way they were recorded by the respondents; Table 2 shows the processed associations, classified on the basis of some common features. For example, Table 1 includes both "information war" and "information" as separate units, while Table 2 shows them as one unit. The tables demonstrate the associations themselves, the number of repetitions (which, consequently, also stands for the percentage, as the experiment was attended by 100 people) and the percentage of the total number of associations (892 units).

The associations presented in Table 1 may be classified on the basis of their meanings as follows: 
Table 1. The most frequent associations with the stimulus "modern war" (5 and more repetitions)

\begin{tabular}{|c|c|c|}
\hline Association & Number of repetitions, un. & $\begin{array}{l}\text { Percentage ratio of the total number } \\
\text { of associations ( } 892 \text { units), } \%\end{array}$ \\
\hline Death & 23 & 2,58 \\
\hline Information war & 22 & 2,47 \\
\hline Ukraine & 18 & 2,02 \\
\hline Mass media & 16 & 1,79 \\
\hline Pain & 14 & 1,57 \\
\hline Blood & 14 & 1,57 \\
\hline Fear & 14 & 1,57 \\
\hline Information & 11 & 1,23 \\
\hline Weapon & 11 & 1,23 \\
\hline Politics & 11 & 1,23 \\
\hline Nuclear weapon & 10 & 1,12 \\
\hline Stupidity & 9 & 1,01 \\
\hline Internet & 9 & 1,01 \\
\hline Lies & 8 & 0,90 \\
\hline Violence & 8 & 0,90 \\
\hline Destruction & 8 & 0,90 \\
\hline Murder & 8 & 0,90 \\
\hline America & 7 & 0,78 \\
\hline Nuclear bomb & 7 & 0,78 \\
\hline Starvation & 7 & 0,78 \\
\hline Victims & 7 & 0,78 \\
\hline Cruelty & 7 & 0,78 \\
\hline Nuclear war & 7 & 0,78 \\
\hline Sanctions & 6 & 0,67 \\
\hline Children & 5 & 0,56 \\
\hline Conflict & 5 & 0,56 \\
\hline Obama & 5 & 0,56 \\
\hline Tears & 5 & 0,56 \\
\hline Suffering & 5 & 0,56 \\
\hline Terror & 5 & 0,56 \\
\hline
\end{tabular}

Type of war: information (22), nuclear (7). Over $20 \%$ of the respondents think that modern war majorly means information war, and $7 \%$ of them think it is nuclear. Moreover, the following types of wars the students associated with modern war were mentioned: ideology war between monarchists and liberals; war between Islam and Europe; war of mathematicians and humanitarians; war between brothers; war for leadership, not for territory; mass media war; generation war; hybrid war; civil war; news war; religious war; secret war; chemical war; economic war (each of the wars was mentioned by one respondent only), atomic war (2). In general the percentage of those who thought modern war to be nuclear may be increased with 
those who mentioned the word "atomic" (2), and the percentage of those who called modern war the information war, may be increased with those who named it the war of mass media and news war.

Modern war tools: mass media (16), information (11), weapon (11), nuclear weapon (10), Internet (9), nuclear bomb (7). The words constituting this group may be divided into three categories: the general notion (weapon), the information war tools (mass media, information, Internet), nuclear/ atomic war weapon (nuclear weapon, nuclear bomb). The second and the third subgroups specify what kind of weapon is meant: in the first case, it is information weapon, and in the second it is nuclear/atomic. Generally, the classification of the war tools into nuclear (18 mentionings) and information (36 mentionings) proves it again that the two major modern war types are information and nuclear. The main tools for information war, according to the respondents, are mass media and Internet. We may suggest that Internet includes the major part of the mentioned mass media (9 of 16), and the specification of others may not be claimed at the present stage of survey data interpretation.

Image of the actions describing modern war: politics (11), sanctions (6), conflict (5). Conflict is confrontation of two or more opposing parties, it may act as the beginning of the war or used as its synonym. One of the possible actions during a conflict is introduction of sanctions, i.e. the measures taken by one party against another, accused party. In the context of this group politics may be interpreted in several aspects. On one hand, it stands for some actions intended to resolve the conflict. On the other, it means the pro-state activity which may lead to a conflict. And finally, in the most general sense, it means activity including sanctions, settlement or encouragement of the conflict.
Names of states: Ukraine (18), America (7). Almost one fifth of the respondents associates modern war with the military conflict which is currently continuing in the territory of Ukraine. The USA is associated with modern war much less frequently. It is worth noticing that besides Ukraine and the USA the respondents also mentioned Russia and China. Consequently, the students consider other states not to be involved in the modern wars.

Political leaders: B. Obama (5). The President of the United States Barack Obama is recalled by students among with the associations with modern war much more frequently than other political leaders (Kolomoysky, Poroshenko, Psaki, Putin, Yatseniuk), however, the respondents do not come up with any judgments of his actions. For this reason it is evident that he is involved in modern wars, but, according to the survey results, it is hard to understand whether he acts as an aggressor or a peace-maker. It is worth noticing that almost all the political leaders mentioned by the students were characterized neutrally, with the only exception of Putin: out of three mentionings, one was definitely positive ("Putin is doing great").

Participants of modern war: victims (7), children (5). It is interesting that the most frequent are the associations denoting the passive participants of war, the parties exposed to its influence. Such associations, as "warriors", "soldiers", "generals", "people", "politicians" are less frequent. Consequently, speaking of modern war it is not the one who initiates and ends it that matters, but those who are forced to get involved and experience the exposure. It is remarkable that modern war causes more suffering to children than to adults.

Attributes of modern war: death (23), pain (14), blood (14), murders (8), lies (8), violence (8), destruction (8), starvation (7), cruelty (7), suffering (5), tears (5). Among the attributes, 
phenomena accompanying modern war, the most frequent is "death", the frequency leader of all the received associations. The majority of the associations included into this group are connected with the damage caused to people. Such associations can also be divided into two subgroups: connected to those exposed to damage; and secondly, connected to those who cause the damage. The first subgroup, therefore, includes: death, pain, blood, starvation, suffering, tears (45 mentionings in total); and the second includes murders, violence, cruelty (23). In numbers, the first subgroup overcomes the second one by almost two times, again pointing at the importance of victims, not the active participants of modern war, who experience the main exposure (see "participants of modern war"). There are two associations that are not directly connected to the damage caused to people: "destructions" and "lies". The association "destruction" may mean that primarily, the damage caused by modern war concerns the people, while the destruction of cities and objects are not that relevant. It is reflected in the frequency of the associations related to people in comparison with "destructions": 68 to 8 . The concept "lies" points at the character of leading modern war, meaning that it is not a fair battle, but that modern war is based on deception and distortion.

Judgmental characteristics of modern war: fear (14), stupidity (9), terror (5). Modern war is evaluated by students as an exclusively negative phenomenon, and the attributes they use are very strong: fear and terror. Modern war does not only inspire fear, but also finds no approval among the respondents; it is described as stupid, which means, irrational, non-conforming to any common sense. The similar attributes are less frequent associations, such as "absurd", "nonsense" etc.

Now let us do the similar work with the associations presented in Table 2; perhaps, it may expand and specify the semantic groups outlined on the basis of the data from Table 1 .

Classification of the separate associations into the group, on one hand, specifies the way the respondents understand modern war, but on the other hand, some of the aspects turn out to be generalized and not possible to specify. It concerns such associations as "information", "cold", "nuclear" etc. that include some characteristics of the studied phenomenon, such as, for instance, "nuclear explosion", "nuclear winter", "nuclear war" etc. Consequently, not all of the semantic groups outlined before may be studied on the basis of the data demonstrated in Table 2. Specifically it concerns the group "type of war" as the characteristics serving as the names of war types (cold, information, nuclear, atomic, chemical) are included into the greater associations: "cold", "information", "nuclear", "atomic", "chemistry". Consequently, they shall be presented in other semantic groups below.

Tools of modern war: information (38), weapon (28), nuclear (23), mass media (18), bomb (13), atom (12), technology (11), explosion (7), chemistry (6), news (5), computer (5), TV (5). Within the current semantic groups we should make several more remarks. First of all, the modern war tools may be divided into two subgroups: related to weapon, arms in the traditional understanding (nuclear, bomb, atom, explosion, chemistry); related to new type wars: information wars (information, mass media, news, computer, TV). The number of associations in this group overcomes that in the first subgroup (71 vs. 61), considering that the first subgroup collects the associations related to different war types while the second one focuses on information war. Consequently, it is information war that is mostly perceived as modern war. Secondly, the research of associations from the first subgroup lets us remark that the contact fights when warriors come face to face with each other has 
Table 2. The most frequent classified associations with the stimulus "modern war" (5 and more repetitions)

\begin{tabular}{|c|c|c|c|}
\hline $\begin{array}{l}\text { Association } \\
\text { group }\end{array}$ & $\begin{array}{l}\text { Number of } \\
\text { repetitions, } \\
\text { un. }\end{array}$ & $\begin{array}{l}\text { Percentage } \\
\text { of the total } \\
\text { number of } \\
\text { associations } \\
\text { (892 units), \% }\end{array}$ & Associations included into the group \\
\hline 1 & 2 & 3 & 4 \\
\hline Information & 38 & 4,26 & $\begin{array}{l}\text { Information war, information, false information, maximum } \\
\text { informative value, lack of information, excessive } \\
\text { information, information interception }\end{array}$ \\
\hline Weapon & 28 & 3,14 & $\begin{array}{l}\text { Bacteriological weapon, biological weapon, with no } \\
\text { weapon, threatening with phantom weapon, weapon, } \\
\text { chemical weapon, nuclear weapon }\end{array}$ \\
\hline Death & 27 & 3,03 & $\begin{array}{l}\text { Meaningless death, massive death, many deaths, death, } \\
\text { death of the young }\end{array}$ \\
\hline Nuclear & 23 & 2,58 & $\begin{array}{l}\text { Nuclear threat, nuclear bombs, nuclear winter, nuclear } \\
\text { weapon, nuclear explosion }\end{array}$ \\
\hline $\begin{array}{l}\text { America, the } \\
\text { USA }\end{array}$ & 18 & 2,02 & $\begin{array}{l}\text { America; America the liberator; two confronting parties: } \\
\text { the block leaded by the USA on one side and Russia on } \\
\text { another; China-the USA; China-the USA-Russia; Russian } \\
\text { and America; the USA; the USA and Russia; the USA vs. } \\
\text { Russia }\end{array}$ \\
\hline Mass media & 18 & 2,02 & $\begin{array}{l}\text { War of mass media, mass media, mass media creating the } \\
\text { picture of the world }\end{array}$ \\
\hline Blood & 16 & 1,79 & Bloodless, bloody, blood, cold-blooded \\
\hline Fear & 15 & 1,68 & Fear, fearsome \\
\hline Politics & 14 & 1,57 & Politics, politicians, political games, political battles \\
\hline Bomb & 13 & 1,46 & $\begin{array}{l}\text { Atomic bomb, bomb, bomb shelter, hydrogen bomb, nuclear } \\
\text { bombs }\end{array}$ \\
\hline Atom & 12 & 1,35 & Atomic war, atom, atomic bomb, atomic central \\
\hline Lies & 11 & 1,23 & False information, false data, false values, lies \\
\hline Peace/world & 11 & 1,23 & $\begin{array}{l}\text { War for peace, peace, world war, can be done peacefully, } \\
\text { world repartition, armistice, polar world, threat to the world } \\
\text { order, destruction of peaceful population, ulcer on the body } \\
\text { of the world }\end{array}$ \\
\hline Destructions & 11 & 1,23 & $\begin{array}{l}\text { Destructions, destroyed cities, destructive war, great } \\
\text { destructions }\end{array}$ \\
\hline Technologies & 11 & 1,23 & $\begin{array}{l}\text { War of technologies, high technologies, computer } \\
\text { technologies, new technologies, modern technologies, } \\
\text { technological }\end{array}$ \\
\hline Victims & 10 & 1,12 & Victims, victimhood, lots of victims, multiple victims \\
\hline Cruelty & 10 & 1,12 & Cruel, cruelty, incredible cruelty \\
\hline People & 9 & 1,01 & $\begin{array}{l}\text { Evil people, zombie people, zombification of people, people, } \\
\text { programming of people, indifference to people, dumb } \\
\text { people, murder of innocent people }\end{array}$ \\
\hline Russia & 9 & 1,01 & $\begin{array}{l}\text { Two confronting parties: the block leaded by the USA on } \\
\text { one side and Russia on another; China-the USA; China-the } \\
\text { USA-Russia; Russia; Russia and America; strong influence } \\
\text { of Russia; the USA and Russia; the USA vs. Russia, farmers } \\
\text { in Russia }\end{array}$ \\
\hline Murders & 9 & 1,01 & Murders, murders of innocent people \\
\hline
\end{tabular}


Continuance Table 2

\begin{tabular}{|c|c|c|c|}
\hline 1 & 2 & 3 & 4 \\
\hline Conflict & 8 & 0,90 & $\begin{array}{l}\text { Military conflict; conflict; conflict covering the majority of } \\
\text { countries; conflicts between countries }\end{array}$ \\
\hline Cold & 8 & 0,90 & Eternal cold; cold war; cold-blooded; cold \\
\hline Explosion & 7 & 0,78 & Big bang, explosions, nuclear explosion \\
\hline Struggle & 6 & 0,67 & $\begin{array}{l}\text { Struggle, struggle of two superpowers through other } \\
\text { countries, struggle for leadership, struggle between } \\
\text { countries }\end{array}$ \\
\hline Children & 6 & 0,67 & Children, orphan asylum \\
\hline Life & 6 & 0,67 & $\begin{array}{l}\text { Life, end of ordinary peaceful life, nothing alive, loss of life } \\
\text { value, better to live }\end{array}$ \\
\hline Suffering & 6 & 0,67 & Suffering, suffering of the innocent \\
\hline USA/RF & 6 & 0,67 & $\begin{array}{l}\text { Two confronting parties: the block leaded by the USA on } \\
\text { one side and Russia on another; China-the USA-Russia; } \\
\text { Russia and America; the USA and Russia; the USA vs. } \\
\text { Russia }\end{array}$ \\
\hline Chemistry & 6 & 0,67 & Chemistry, chemical weapon, chemical war \\
\hline Insanity & 5 & 0,56 & Insanity, crazy smile \\
\hline Loss & 5 & 0,56 & Loss, loss of the living, loss of the innocent \\
\hline Computer & 5 & 0,56 & Computer, computer games, computer technologies \\
\hline Leader & 5 & 0,56 & $\begin{array}{l}\text { Struggle for leadership, war not for the territory but for } \\
\text { leadership, leader, the PRC as a leader }\end{array}$ \\
\hline People & 5 & 0,56 & $\begin{array}{l}\text { International relations, peoples, brother peoples, elimination } \\
\text { of peaceful people }\end{array}$ \\
\hline News & 5 & 0,56 & News, news war \\
\hline TV & 5 & 0,56 & TV, television, TV set \\
\hline Economic & 5 & 0,56 & $\begin{array}{l}\text { Economy, economic war, economic carousel, economic } \\
\text { crisis, economic recession }\end{array}$ \\
\hline
\end{tabular}

lost its relevance nowadays. Modern war means use of bombs, chemical and nuclear weapon. Thirdly, associations from the second subgroup helped us to clarify the source of information as a tool of modern war: it is not only the Internet that has been proved before, but also television, and news as a whole, no matter which mass media it belongs to.

Image of the actions characterizing modern war: politics (14), conflict (8), struggle (6), economic (5). The similar group presented on the basis of Table 1 was expanded at the expense of associations "struggle" and "economic". Struggle may point at the fact that conflicts of modern wars are more likely to transform into long-lasting struggle rather than get settled. "Economic" may acts as a characteristic both for the conflict and the sanctions implemented by the parties.

Names of states: America (the USA) (18), Russia (9), the USA-Russia (6). This semantic group helped us to understand which countries are mostly related to modern war in the idea of the respondents: these are the USA and Russia. In a series of cases the respondents directly pointed at the confrontation of these two countries: "the USA vs. Russia". It is interesting that the number of mentionings of the USA in all possible variations caught up with "Ukraine". One cannot help but connect such figures and confrontation of the USA and Russia. These factors witness 
that modern war is the one happening between two countries, the USA and Russia, for the third state which is Ukraine. The third party involved into the relations of the USA and Russia is China, but its role in the events around Ukraine is less significant, according to the students' opinion.

Participants of modern war: victims (10), people (9), children (6), people (5), leader (5). In regard of the associations gathered in this semantic group we should notice that the role of the leader is not as great as that of other actors.

Attributes of modern war: death (27), blood (16), destructions (11), lies (11), cruelty (10), murders (9), suffering (6), cold (8), loss (5). The semantic group of the associations shown in Table 1 was expanded with "cold" and "loss". "Loss" only increases the number of associations related to the exposure to the effects of war. "Cold", on one hand, acts as an attribute of one of the possible types of modern war - cold war, which also points at the time the responds relate the emergence of the new, modern type of wars with - late 20 century. On the other hand, it is another negative association characterizing modern war with darkness, dust etc.

Judgmental characteristics of modern war: fear (15), insanity (5). The expansion of this semantic group occurred with the association "insanity" which also witnesses the disapproval of modern war by the respondents, just like the association "stupidity" but in a stronger way.

Phenomenon threatened by modern war: peace/world (11), life (6). Without references to the phrases these terms constituted, we could unite them into the group titled "Phenomena confronting modern war". However, almost all examples of their use ("threaten to the world order", "ulcer on the body of the world", "world repartition", "end of life", "nothing alive" etc.) mean that life and peace are the two things that are the first to be exposed to modern war.

To conclude, we have listed the major characteristics of modern war revealed in the process of the free association experiment. The first modern war, as understood by the student audience, is Cold war, the war of the late 20 century. Its main participants were the USA and the USSR, and today the states most frequently associated with modern war are the same: the USA and Russia, the successor of the Soviet Union. Ukraine is next to the USA in the number of mentionings, as in its territory another modern war is happening at the moment. It is worth noticing that if the respondents mentioned the countries participating in the war, they find the leaders of such countries less significant. B. Obama, V. Putin, A. Yatseniuk, A. Poroshenko, J. Psaki are mentioned much less, occasionally. In general, we observe the absence of any personified activists of modern war: soldiers, generals, warriors are hardly ever mentioned by the students. Their attention is concentrated on the suffering party, on the victims: people, nations, and most of all, on children. The discreetness and covertness of the aggressors and active participants of modern war may be explained by the types of wars it is usually associated with, not with the tools of leading it. Thus, modern war is, first of all, an information war, leaded by mass media, Internet, news and television. The second most frequently named type of war is nuclear (atomic) with its attributive explosions, bombs, nuclear winter etc. Both varieties of modern war prove that contact battles face to face have lost their relevance: modern war uses other means. For instance, these are the means that throughout the major part of the 20 century could not be thought as weapons, which are the images broadcast through television and computers. 


\section{References}

1. Akopov G.L. Fenomen informatsionnykh voyn $v$ seti INTERNET $i$ ego vozdeystvie na sovremennuiu politiku [Phenomenon Of Information Wars In The INTERNET And Its Impact On Modern Politics] // Gosudarstvennoe i munitsipal'noe upravlenie. Academic notes of North Caucasian Academy of Civil Service № 1. P. 86-102.

2. Antiushin S.S. Sovremennuyu voynu ne vyigrat'. Nasha zadacha eio predotvradit' [Modern War Cannot Be Won. Our Task Is To Prevent It] // Bezopasnost’ Evrazii, 2014. № 1 (47). P. 97-108.

3. Batay Zh. Prokliataia Chast' [The Damned Part]. Moscow: Ladomir, 2006.

4. Bondarenko T.A. Stereorip vospriiatiia organov v Dal'nevostochnom regione [State Bodies' Stereotypes In The Far East Region] // Sotsiologicheskie issledovaniia, 2006. № 1. P. 99-103.

5. Burenok V.M. Bazis sleduiuschego pokoleniia voyn [Basis Of The Next Generation Wars] // Military Science Academy Newsletter. 2001. № 3 (36). P. 32-37.

6. Voyna [War]. Electronic source. Access at: ttps://ru.wikipedia.org/wiki/\%D0\%92\%D0\%BE\% $\mathrm{D} 0 \% \mathrm{~B} 9 \% \mathrm{D} 0 \% \mathrm{BD} \% \mathrm{D} 0 \% \mathrm{~B} 0$

7. Dem'iankov V.Z. Poniatie i kontsept $v$ khudozhestvennoy literature i nauchnom iazyke [Term And Concept In Fiction And Language Of Science] // Voprosy filosofii. Moscow, 2001. № 1. P. 35-47.

8. Eliakov A.D. Informatsionnye tekhnologii i sovremennaia voyna [Information Technologies And Modern War] // Svobodnaia mysl'. 2008. № 1. P. 181-194.

9. Zamaraeva Yu.S. Osobennosti sotsiokul'turnykh transformatsiy migratsionnykh protsessov $v$ XX nachale XXI veka [Peculiarities Of Migration Processes Sociocultural Transformations In The 20 early 21 centuries] // Sovremennye problemy nauki i obrazovaniia. 2014. № 2. P. 649.

10. Zamaraeva Yu.S. Osobennosti etnicheskoy migratsii $v$ sotsial'no-psikhologicheskom vospriiatii (na materiale analiza rezul'tatov eksperimenta po metodike "Seriynye tematicheskie assotsiatsii") [Peculiarities Of Ethnic Migration In The Social And Psychological Aspect (Based On Experiment Under "Serial Themed Associating" Method)] // Sotsiodinamika. 2014. № 9. P. 63-82. DOI: 10.7256/2306-0158.2014.9.13407. URL: http://e-notabene.ru/pr/article_13407.html

11. Zusman V. Kontsept $v$ sisteme gumanitarnogo znaniia [Concept Within Humanitarian Knowledge System] [Electronic source] // Voprosy literatury. 2003. № 2 Access at: http://magazines. russ.ru/voplit/2003/2/zys.html

12. Il'beykina M.I. Rol'vizual'noy antropologii v sotsial'nom konstruirovanii tsennostey [Visual Anthropology Role In Social Values' Construction]. Dissertation for the degree of Candidate of Philosophy, subject 09.00.11 Social Philosophy. Krasnoyarsk, 2013.

13. Il'beykina M.I. Sovremennye muzeynye praktik: 2000-2012 gg. [Modern Museum Practices: Years 2000-2012] // Sovremennye problemy nauki i obrazovaniia. 2013. № 1. P. 399.

14. Karlova O.A., Koptseva N.P., Kirko V.I., Reznikova K.V., Zamaraeva Yu.S., Sertakova E.A., Kistova A.V., Moskviiu Iu.N., Viktoruk E.A., Tarasova M.V., Komaritsy S.G., Pavlova I.P. , Pavlov P. A., Shishatskiy N.G., Nevzorov V.N. Novoe buduschee Sibiri: ozhidaniia, vyzovy, resheniia [New Future Of Siberia: Expectations, Challenges, Solutions]. Krasnoyarsk, 2013.

15. Waltz, Kenneth. SSHA zhdiot medlennyy upadok [The USA Is Coming To Slow Recession]. Electronic source. Access at: http://www.geopolitica.ru/article/kennet-uoltc-ssha-zhdet-medlennyyupadok\#.VDASWWd_uSq 
16. Kirko V.I., Bakhova N.A., Koptseva N.P. , Zamaraeva Yu.S. Problema sotsiokul'turnykh issledovaniy $v$ sovremennoy gumanitarnoy nauke [Problem Of Sociocultural Research In Modern Humanitarian Science] // Sovremennye problemy nauki i obrazovaniia. 2012. № 3. P. 323.

17. Kirko V.I., Koptseva N.P. Etnicheskie kharakteristiki $i$ ikh analitika $v$ sovremennykh gumanitarnykh issledovaniiakh [Ethnical Characteristics And Analytics In Modern Humanitarian Research] // Sovremennye problemy nauki i obrazovaniia. 2014. № 3. P. 793.

18. Kistova A.V. Etnograficheskiy metod $v$ sotsial'no-gumanitarnykh issledovaniiakh [Ethnographic Method In Social And Humanitarian Research] // Sovremennye problemy nauki i obrazovaniia. 2013. № 6. P. 900.

19. Kistova A.V. Konstruirovanie etnokul'turnoy i obschenatsional'noy identichnostey na osnove etnograficheskogo podkhoda v sotsial'noy filosofii [Constructing Ethnocultural And General National Identities Based On Ethnographic Approach To Social Philosophy]. Dissertation for the degree of Candidate of Philosophy, subject 09.00.11 Social Philosophy. Krasnoyarsk, 2013.

20. Kovaleva L.V. Natsional'noe svoeobrazie iazykovoy ob'ektivizatsii kontseptov, vyrazhaemykh frazeosochetaniiami, oboznachaiuschimi realii okruzhaiuschey sredy [National Identity Of Linguistic Objectivation Of The Concepts Expressed With Fixed Phrase Combinations Denoting Environment Realities] // Voronezh State University Newsletter. 2004. № 1. P. 54-60.

21. Kovtun N.V. Roman V.F. Odoevskogo "4338 god" i traditsii intellektual'noy utopii v Rossii [Novel "Year 4338” By V.F. Odoevsky And Russian Intellectual Utopia Traditions] // Tomsk Polytechnic University Newsletter. 2004. Vol.307. № 5. P. 179-183.

22. Kovtun N.V. Bogobortsy, fantaziory i trikstery v pozdnikh rasskazakh V.M. Shukshina [Theomachists, Fantasists And Tricksters In Late Short Stories By V.M. Shukshin] // Literaturnaia uchioba. 2011. № 1. P. 132-154.

23. Kolesnik M.A. Spetsifika ponimaniia slova "Rodina" studentami Sibirskogo federal'nogo universiteta [Peculiarities Of Understanding Of "Motherland" By Students Of Siberian Federal University] // Sovremennye problemy nauki i obrazovaniia. 2014. № 2. P. 648.

24. Kolesnik M.A. Sotsiologicheskie issledovaniia voobrazheniia v 30-80-e gg. XX veka [Sociological Research Of Imagination In The 30-80s Of The 20 Century] // Sociodynamics. 2014. № 11. P. 45-61. DOI: 10.7256/2306-0158.2014.11.13517. URL: http://e-notabene.ru/pr/article_13517. html

25. Koptseva N.P. Kul'turologicheskaia baza formirovaniia obschenatsional'noy rossiyskoy identichnosti v sibirskikh regionakh Rossiyskoy Federatsii [Culturological Base For Forming General Russian National Identity In The Siberian Regions Of The Russian Federation] // Volgograd State University Newsletter. Series 7. Philosophy. Sociology and Social Technologies. 2012. № 3. P. 11-15.

26. Koptseva N.P. , Kirko V.I. Etnicheskie kharakteristiki $i$ ikh analitika $v$ sovremennykh kul'turnykh issledovaniiakh [Ethnic Characteristics And Analytics In Modern Cultural Research] // Sovremennye problemy nauki i obrazovaniia. 2014. № 3. P. 793.

27. Krasova E. Spetsifika assotsiativnogo eksperimenta $v$ issledovanii obrazov politikov [Free Association Experiment Specifics Of Studying Images Of Politicians] // Nauchno-kul'turologicheskiy zhurnal. 2010. № 13. Electronic Source. Access at: http://www.relga.ru/Environ/WebObjects/tguwww.woa/wa/Main?textid=2706\&levell $=$ main\&level2 $=$ articles 
28. Libakova N.M. Modifikatsii gendernykh obrazov v rossiyskoy kul'ture kontsa XIX nachala XXI veka [Modification Of Gender Images In Russian Culture Of Late 19 - Early 21 Centuries]. Dissertation for the degree of Candidate of Philosophy. Krasnoyarsk, 2011.

29. Libakova N.M. Sotsial'no-psikhologicheskie osobennosti formirovaniia gendernykh obrazov $v$ srede rossiyskogo studenchestva (rezul'taty assotsiativnogo eksperimenta) [Social and Psychological Peculiarities Of Gender Image Formation In The Russian Students' Medium] // Sociodynamics. 2014. № 10. P. 101-134. DOI: 10.7256/2306-0158.2014.10.13435. URL: http://e-notabene.ru/pr/article_13435. html

30. Luzan V.S. Znachenie kul'turnoy politiki v razvitii instituta gosudarstvennosti [Cultural Policy Role In Nation-Building Institute Development] // Sotsiogumanitarnyy vestnik. 2010. № 1(4). P. 145-148.

31. Luzan V.S. Sotsial'no-filosofskiy analiz dinamiki gosudarstvennoy kul'turnoy politiki Rossiyskoy Federatsii [Social And Philosophic Analysis Of State Cultural Policy Dynamics]. Dissertation for the degree of Candidate of Philosophy, subject 09.00.11 Social Philosophy. Krasnoyarsk, 2011.

32. Luzan V.S. K probleme kontseptual'nykh osnovaniy kul'turnoy politiki [To The Problem Of Conceptual Grounds OfCultural Policy] // Sotsiodinamika. 2014. № 10. P. 135-158. DOI: 10.7256/23060158.2014.10.13420. URL: http://e-notabene.ru/pr/article_13420.html

33. Liutkene G.V. Sovremennye kontseptsii voyny [Modern War Concepts]. Dissertation for the degree of Candidate of Political Science. Moscow, 2011.

34. Mineev V.V. Ukhod iz zhizni: sotsial'no-filosofskiy rakurs [Departure From Life: Social And Philosophic Perspective]. Moscow: Direct-Media, 2014.

35. Nazarov A.I., Sokolov R.V. Assotsiatsiia $i$ assotsiativnyy eksperiment: raznye sud'by [Association And Free Association Experiment: Different Fates] // Voprosy psikhologii. 2007. № 4. P. $125-138$.

36. Neretina S.S. Tropy i kontsepty [Tropes And Concepts]. Electronic source. Access at: http:// polittheory.narod.ru/Neretina/Tropes_and_concepts/1.htm

37. Nikishina I.Iu. Vyrazhenie kontsepta "gnev" $v$ sovremennoy angliyskoy $i$ amerikanskoy khudozhestvennoy literature [Realization Of Fury Concept In Modern British And American Fiction]. Author's thesis of the dissertation for the degree of Candidate of Philology. Moscow, 2008.

38. Palkin A.D. Assotsiativnyy eksperiment kak sposob kross-kul'turnogo issledovaniia obrazov soznaniia [Free Association Experiment As A Way Of Cross-Cultural Research Of The Conscience Images] // Voprosy psikhologii. 2008. № 4. P. 81-89.

39. Pozdniakova O.A., Reznikova K.V. Osobennosti sub'ektov khudozhestvennoy kinokommunikatsii [Peculiarities Of Artistic Cinema Communication Subjects] // Sovremennye problemy nauki i obrazovaniia. 2013. № 4. P. 385.

40. Popova T.V. Assotsiativnyy eksperiment v psikhologii [Free Association Experiment In Psychology] (coursebook). Moscow: Flinta: MPSI, 2006.

41. Pautova L.A. Assotiativnyy eksperiment: opyt sotsiologicheskogo primeneniia [Free Association Experiment: Sociological Application Experience] // Sotsiologiia: metogologiia, metody i matematicheskoe modelirovanie (Sotsiologiia: 4M). 2007. № 24. P. 149-168. 
42. Razumovskaia V.A. K voprosu ob unifikatsii nauki, iskusstva i perevoda [To The Issue Of Unifying Science, Art And Translatio] // Newsletter of Saint Petersburg University of Economy and Finance. 2011. № 3. P. 32-36.

43. Razumovskaia V.A. Simmetriia khudozhestvennykh tekstov i perevodov [Symmetry Of Literary Texts And Translations] // Iazyk i kul’tura. 2010. № 4. P. 30-43.

44. Reznikova K.V. Znachenie kinematografa dlia formirovaniia obscherossiyskoy natsional'noy identichnosti [Role of Cinematograph In Forming General Russian National Identity] // Sovremennye problemy nauki obrazovaniia. 2013. № 3. P. 416.

45. Speech of Pope Francis, Septmeber 13, 2014. Electronic source. Access at: http://www.bbc. co.uk/russian/rolling_news/2014/09/140913_rn_pope_third_world_war.shtml?ocid=socialflow_ facebook

46. Rogozin D.O., Danilevich A.A., Loskutov D.V., Rogozin A.D., Rogozin O.K., Semin V.V. Voyna i mir v terminakh i opredeleniiakh [War And Peace In Terms And Definitions]. Military and Political Dictionary. Electronic source. Access at: http://www.voina-i-mir.ru/

47. Russian Associative Dictionary. Associative Thesaurus of Modern Russian Language. Volume 1. Direct Dictionary: From Stimulus To Reaction. Volume 1. / Iu.N. Karaulov et al. Moscow: Pomovsky i partnery, 1994.

48. Russian Associative Dictionary. Associative Thesaurus of Modern Russian Language. Volume 2. Reverse Dictionary: From Reaction To Stimulus. Volume 1. / Iu.N. Karaulov et al. Moscow: Russian Language Institute of Russian Academy of Science, 1994.

49. Russian Associative Dictionary. Associative Thesaurus of Modern Russian Language. Volume 3. Direct Dictionary: From Stimulus To Reaction. Volume II. / Iu.N. Karaulov et al. Moscow: Russian Language Institute of Russian Academy of Science, 1996.

50. Russian Associative Dictionary. Associative Thesaurus of Modern Russian Language. Volume 4. Reverse Dictionary: From Reaction To Stimulus. Volume II. / Iu.N. Karaulov et al. Moscow: Russian Language Institute of Russian Academy of Science, 1996.

51. Semenova A.A. Modifikatsii drevnerusskogo kontsepta "gosudarstvo" v rossiyskoy kul'ture XXI veka (metodologicheskiy aspekt) [Modifications Of Ancient Russian Concept For "State" In Russian Culture Of The 21 Century (Methodological Aspect)]. Dissertation for the degree of Candidate of Philosophy. Krasnoyarsk, 2009.

52. Seredkina N.N. Konstruirovanie pozitivnoy etnicheskoy identichnosti v polikul'turnoy sisteme [Constructing Positive Ethnic Identity In A Polycultural System]. Author's Thesis of the Dissertation for the degree of Candidate of Philosophy, subject № 09.00.11 Social Philosophy. Krasnoyarsk, 2013.

53. Seredkina N.N. Etnicheskaia kartina mira v kontekste sovremennykh sotsial'nykh issledovaniy [Ethnical World Outlook In The Contest Of Modern Social Research] // Sotsiodinamika. 2014. № 10. P. 26-59. DOI: 10.7256/2306-0158.2014.10.13441. URL: http://e-notabene.ru/pr/article_13441.html

54. Sertakova E.A. Kontsept «gorod» v russkoj kul’ture [Concept Of «City» In Russian Culture] // Chelovek I kul'tura. 2014. № 2. P. 97-126.

55. Sertakova E.A. Sotsial'nyy konstruktivizm kak kontseptsiia konstruirovaniia etnosa [Social Constructivism As A Concept Of Ethnos Building] // Sovremennye problemy nauki i obrazovaniia. 2013. № 6. P. 999. 
56. Sitnikova A.A. Sovremennye praktiki forsayt-issledovaniia buduschego sotsial'noatropologicheskikh system, $v$ tom chisel etnokul'turnykh grupp severnykh regionov Rossiyskoy Federatsii [Modern Foresight Practices For Research Of The Future Of Social And Anthropological Systems, Including Ethnocultural Groups Of The Northern Regions Of The Russian Federation] // Sotsiodinamika. 2014. № 9. P. 44-62. DOI: 10.7256/2306-0158.2014.9.13405. URL: http://e-notabene. ru/pr/article_13405.html

57. Stepanov Iu.S. Kontsepty. Tonkaia plionka tsivilizatsii [Concepts: The Thin Membrane Of Civilization]. Moscow: Iazyki Slavianskikh Kul'tur, 2007.

58. Toffler, A. Voyna i antivoyna. Chto takoe voyna i kak s ney borot'sa? Kak vyzhit' na rassvete XXI veka? [War And Anti-War]. Moscow: AST. Tranzitkniga, 2005.

59. Uchenye: shimpanze prirodnye ubiytsy [Scientists: Chimpanzees Are Natural Born Killers]. Electronic source. Access at: http://www.bbc.co.uk/russian/science/2014/09/140918_chimp_killers. shtml

60. Huntington, S. Stolknovenie tsivilizatsiy? [Clash Of Civilizations] Electronic source. Access at: http://gtmarket.ru/laboratory/expertize/2007/2498. Дата размещения: 20.01.2007.

61. Jung, C.G. Tavistokskie lektsii [Tavistock Lectures]. Electronic source. Access at: http://www. gramotey.com/?open_file=1269062729

62. Bouthoul, Gaston: «Linfanticide différé» (deferred infanticide), Paris 1970.

63. Goldstone, Jack A.: «Revolution and Rebellion in the Early Modern World», Berkeley 1991.

64. Gunnar Heinsohn. Söhne und Weltmacht: Terror im Aufstieg und Fall der Nationen, Orell Füssli, Zürich, 2003.

65. Holsti K.J. 1996. The State, War, and the State of War. New York: Cambridge Univ.Press. $254 \mathrm{pp}$.

66. Elshtain J.B. Women and War. New York: Basic Books6 1987. 288 pp.

67. Enloe C. 1990. Bananas, Beaches and Bases.Berkeley: Univ. Calif. Press, 100-. 244 pp.

68. Levy J.S. The causes of war and the conditions of peace. Annu. Rev. Polit. Sci. 1998. 1: 141p.

69. Levy J.S. War in the Modern Great Power System, 1495.1975. Lexington: Univ. Press Kentucky. 215 pp

70. Libakova NM, Sitnikova AA, Sertakova EA, Kolesnik MA, Ilbeykina MI. Interaction of the Yakut ethnicity and biological systems in the territory of the Sakha Republic (Hordogoy settlement, Suntarsky District) and Krasnoyarsk Krai (Essey settlement, Evenks District). Life Sci J 2014;11(6s):585592.

71. Libakova NM, Sitnikova AA, Sertakova EA, Kolesnik MA, Ilbeykina MI. Modern practices of regional and ethnic identity of the Yakuts (North Asia, Russia). Life Sci J 2014;11(12):133-140.

72. Peterson V.S. 1992. Gendered States. Boulder, CO: Lynne Rienner. 1992. 225 pp.

73. Pivovarov D.V. Objective and Subjective Religiousness // Journal of Siberian Federal University. Humanities \& Social Sciences 2 (2008 1) 250-252.

74. Rasler KA, Thompson WR. 1994. The Great Powers and Global Struggle, 1490.1990. Lexington: Univ. Press Kentucky. 275 pp.

75. Reznikova K.V., Zamaraeva Yu.S., Kistova A.V., Pimenova N.N. The current state of traditional socio-cultural practices of indigenous peoples of the North (on the example of cultures of Selkups, Nenets and Essey Yakuts). Life Sci J 2014;11(12):126-132. 
76. Richard A. Gabriel. No More Heroes: Madness and Psychiatry In War. Hill and Wang; Reissue edition, 1988.

77. Singer J.D., Small M. The Wages of War, 1816. 1965: A Statistical Handbook. New York: Wiley. 1972. 419 pp.

78. Sylvester C. Feminist Theory and International Relations in a Postmodern Era. New York: Cambridge Univ. Press, 1994. 265 pp.

79. Tsvetova N. S. Orthodoxy Eshatological and National Understanding // Journal of Siberian Federal University. Humanities \& Social Sciences 4 (2008 1) 531-538.

80. Vasques J.A. The War Puzzle Revisited. Cambridge: Cambridge University Press, 2009.

81. Waltz K.N. 1988. The origins of war in neorealist theory. J. Interdiscip. Hist. 18.

\title{
Современная война как культурный феномен.
}

\section{Причины войны. Результаты ассоциативного эксперимента}

с ассоциатом «современная война»

(на материале исследований в студенческих группах

Сибирского федерального университета)

\author{
Н.П. Копцева, К.В. Резникова \\ Сибирский федеральный университет \\ Россия, 660041, Красноярск, пр. Свободньй, 79
}

Предметом исследования выступают образы и конщепты коллективного восприятия современной войны в современной молодежной студенческой среде. В ходе исследования были привлечены наиболее актуальные теоретические, концептуальные, методологические позиции, характерные для зарубежных и отечественных исследователей международных отношений, военных конфликтов, специфики современной войны, аналитики причин современных войн. В ходе эмпирического исследования был применен метод ассочиативного эксперимента по методике Назарова и Соколова. Ассоциатом выступило понятие «современная война». $K$ эмпирическому исследованию были привлечены 100 студентов Сибирского федерального университета, которые обучаются по техническим и гуманитарным направлениям. Получено около 900 ассочиаций, классифицированных по типам, качественным признакам. Результаты были обработаны и проинтерпретированы. Наиболее часто встречающие ассочиации к ассоииату «современная война» - «информационная война» и «ядерная война». Коллективное восприятие современной войны в молодежной студенческой среде Сибирского федерального университета может быть экстраполировано на более иирокие сочиальные страть молодежи и студенчества русскоязычной части граждан Российской Федерачии. Результать исследования могут быть применены при принятии политических решений, при планировании программ молодежной политики, патриотического воспитания, а также для адекватного восприятия молодежной среды Красноярского края.

Ключевые слова: современная война, причины войны, уровневый анализ, национальный (государственный) уровень, ассоциативный эксперимент, концепт, студенчество, Сибирский федеральный университет, информационная война, национальная безопасность.

Научная специальность: 24.00.00 - культурология, 09.00.00 - философские науки. 